\title{
The setting of a coalition contract between controlling shareholder, managers and executives: How to mix incentive and political logics?
}

\author{
Hubert de La Bruslerie* \\ Professor of finance \\ University Paris Dauphine \\ DRM Finance \\ Place du Mal de Lattre 75116 Paris mail : hlb@dauphine.fr
}

\begin{abstract}
The leveraging of control is the possibility for the controlling shareholder to lower his direct participation in capital through a convergence of financial and economic interest with other shareholders in the firm. In this paper, the setting of a coalition contract is done by awarding stocks to managers and executives. This paper analyses it jointly, on one side, in a rationale of economic incentive and, on the other side, in a rationale of political coalition of the initial dominant shareholder with managers and executives/employees. It is shown that the two logics are not opposite but complementary. The sharing of the private benefits within members of the new coalition is at the heart of a new implicit contract. The initial controlling shareholder "buys" efficient efforts by awarding a stake of capital to managers or executives, but also by allowing them to share a part of the private benefits and to join a new dominant group. Even if the effort function of the executives is weakly productive, a targeted broad diffusion of new stocks may still respect the coherence between an economic incentive rationale and a political substitution rationale.
\end{abstract}

\section{JEL: G3/G32/D74}

Keywords: Ownership structure, private benefits, stock ownership plans, employees' incentives, coalition contract, control.

$12 / 06 / 2010$

\footnotetext{
* This paper was presented at the French Finance Association at the Paris meeting and at the seminar of finance at HEC Geneva. I want to thank Julien Le Maux for his remarks.
} 


\section{The setting of a coalition contract between controlling shareholder, managers and executives: How to mix incentive and political logics?}

\section{Introduction}

The idea that managers, executives and employees stock ownership can become a tool in optimizing the power of control by a dominant shareholder is not new. The empirical analysis of executive stock option plans or employee equity ownership as a defense measure to keep the control of a firm has been proposed in the United States context by Dhillon and Ramirez (1994) or Park and Song (1995) or in France by Desbrières (1997a). In analyzing stock option or stock ownership plan mechanisms, the standard incentive theory considers, on one side, the managers and/or the employees and, on the other side, the shareholders considered as a whole group. It seems more convenient to refer to the existence of a controlling group among the shareholders (cf. La Porta et al., 2000). A situation of a control is a documented empirical fact in many European or Asian countries. This question is now addressed even in the United States (Holderness, 2009). Appropriation of private benefits of control is the consequence of a situation of control.

Stock options and stock ownership plans are categories of incentive contracts allowing managers and executives to appropriate themselves a part of the economic profit of the firm. Stock options are often viewed as limited to top managers and are questioned as too concentrated in the firm, particularly in European countries. The concentration of stock options to top managers in Europe doesn't follow the American custom to diffuse options to middle management and to executives in the firm. In this paper, we focus on a stylized stock ownership plan and its diffusion between two categories of beneficiaries: managers and executives. The analysis will be developed on two different dimensions: an economic rationale of incentive and a political rationale of collusion between the initial controlling shareholder and new partners to form a new controlling group. Awarding stock ownership plan can satisfy both logics, so their diffusion in firms is doubly explained. We will introduce the idea of leverage of control in the sense of a political and economical rationale for collusion. A new controlling group is politically searched by the initial controlling 
shareholder for he/she can relatively reduce his investment in the firm and still hold the bulk of the political power. Furthermore, on the financial ground, he will limit his wealth underdiversification. The concept of "leverage of control" means that the power is still in the hand of the initial controlling shareholder, but he shares it with allied. He/she continues to appropriate private benefit, but he has now to share it. The economic incentive of managers and others employee who may create more value is acknowledged in a framework of asymmetry of information as far as the controlling shareholder do not know exactly the future gain in cash flow. Beside their economic logic of incentive and beside the desire of top managers to entrench, the large diffusion of stocks or stock options to others executives or employees of the firm is explained by the existence of a "political" leverage. We consider that the incentive hypothesis is true and that stimulated managers and executives will produce some effort. The analysis takes into account that awarding new shares through stock ownership plans (or stock option plans) implies a dilution effect for the existing shareholders and that sharing the power will also imply a sharing of the private benefits of control.

We analyze the trade-off and complementarities between the economic logic of incentive and the political logic of leverage of control. We show that stock ownership plans are a tool for leverage of control in a political logic of collusion. The research of a leverage of control by awarding new stocks takes place in a double logic of economic creation of value through incentives and of substitution of the initial dominant shareholder by managers and executives. Respecting the global maintenance of control, both logics are strictly compatible and push in the same direction. The sharing of the private benefits in the new dominant group with managers is a strong motivation for managers and employees to join the new controlling group. We show that there is generally enough room to negotiate what is an implicit contract of coalition. The large diffusion of stocks to other categories of executives (or employees) may still respect the coherence between the economic incentive logic and the political substitution logic. Awarding employees with weakly efficient stock (option) plans finds a "political" explanation. If the economic incentive is globally strong at the executives' level, a positive leverage of control develops in favor of the shareholders and both economic and political logics converge. Nevertheless, even if the executives' effort functions are weakly productive, we show that a joint equilibrium is still possible, but the dominant shareholder will have then to consider a trade-off between economic and political logics. In that sense, this paper brings some explanation to largely diffused stock option or stock ownership plans and on the setting of an implicit coalition contract. 
The paper is organized as follows. The first Section analyzes the literature crossing leverage of control and stock option/stock ownership incentive plans. Section 2 gives the assumptions of the model of stock awarding to employees; the third section analyses the condition for setting a coalition contract with the efficiently stimulated managers. The fourth Section enlarges the model by identifying two groups of managers and middle executives in the firm. A conclusion draws the main results and points out the perspectives.

\section{1-Leverage of control: A review of literature}

The leverage of control is the possibility for the controlling shareholder to lower his direct participation in capital through a convergence of financial interest with other stakeholders in the firm. The different mechanisms of incentive contracts and financial contracts are the background for negotiations that most often take the form of employees stock ownership plans (ESOPs) or contracts of stock options. The former is an incentive mechanism which implies an initial decision to buy shares. ESOPs are generally offered to a large number of (or all) employees. An institutional framework exists in most countries where ownership plans are encouraged and are tax deductible. For instance, in France a new regulation allows a discount in employees stock subscription up to $30 \%$ of the share price, and the "Loi de Modernisation Sociale" gives the employees a seat at the board as soon as their stock ownership is above $3 \%$ of the capital. In the US, Oyer et al. (2004) studied the breadth of stock options plans through the firm's employees using the Bureau of Labor statistics who defines broad-based stock option plans as those awarded at least to $20 \%$ of the employees. Considering a sample of stock options of any kind awarded in 1999 in public or private firms, $52 \%$ of them were «Broad plans ». Looking only at public firms the proportion of those having implemented «Broad plans » in 1999 increases to $11.8 \%{ }^{1}$. The stock options awarded to «non-executives » represented, at that time, $4.4 \%$ of the outstanding shares of these firms.

The importance of the leverage of control can be underlined both through the issue of stock options plans and employee stock ownership plans, although these two contracts are different. The large diffusion of stock options is particularly common in the United States. The systematic award of options plans to the management of the firm, but also to its executives and employees, leads Hall et Murphy (2003) to the idea that too many options are given to too 
many people in a way that is not economically efficient and is ignoring their real cost. Considering the firms of the S\&P 500 Index, the total amount of stock options given to all the employees was estimated to 141 billions USD in $2002^{2}$. The proportion awarded to the first manager represents $4.2 \%$ of the grand total, that awarded to the 5 others most important managers is $5.3 \%$. It results that $90.5 \%$ of the stock options issued in the US will benefit to executives and employees. According to Hall and Murphy, the executives and employees' proportion has been increased from $85 \%$ of the total, in the years 1990, to more than $90 \%$ in 2002. The large diffusion of stock options in the US firms is also figured out by the number of employees who own stock options: there were 1 million people in 1992, but the figure is estimated between 7 and 10 millions in $2000^{3}$.

The potential equity shares involved by the exercise of stock options plans are also very important in the US context. They make the stock options holders an important player, both effectively and potentially, in the ownership structure. Hall and Murphy (2003) outline the importance of the average annual issued flow of stock options issued by the all the firms from the S\&P 500 index, the S\&P Mid-cap 400 index and the S\&P small-cap 600 index during the 1993-2001 period. This figure is given in percentage of the existing outstanding capital and will strongly depend if firms belong to the so-called "New economy" $5.76 \%$ or refer to the "Old economy". Even if we consider a firm belonging to a traditional sector of the economy who issues annually $2.3 \%$ of its capital in stock options, a simple linearization over a 10 years period will mean that $23 \%$ of his capital will potentially belong to the managers and the employees. That share of capital is highly significant in the ownership and could modify the structure of power within the firm.

Stock option plans should not be viewed as some percentage of capital punctually given to managers, other executives and employees. Stock option plans are annually renewed and take place in a long term perspective. More precisely, we know that resetting or replacing plans were common when the situation of the firm does not improve or deteriorates, as it was in the years 2000. A lot of stock options plans became then very "out of the money" and were considered to expire worthless. Resetting the conditions or canceling an existent plan can be complex. New cumulative plans set at lower exercise price will then appear to maintain the incentive pressure and are stacked with the others. On the other hand, if the economic profit of the firm increases, old stock options become "in the money" and new ones are given as a reward and to maintain the incentive pressure. These asymmetric dynamic in stock options 
time process should be underlined (cf. Yermack, 1997 or Ross, 2004). We therefore consider that long term stacked and exercised stock option plans will lead to the issue of new stocks and will have an ex ante dilutive effect.

It is easier to analyze employee direct stock ownership in the context of a leverage of control. The issuance of new stocks modifies the controlling ownership structure. It is pointed out in France by Trebucq (2002) who shows that the relative weight of the first shareholders is clearly less when a firm developed an employee stock ownership (15.8\% of the shares versus $41.0 \%$ for non family firms and $33.3 \%$ versus $46.1 \%$ considering family firms). For non family firms, the leverage of control can represent $35 \%$ of the initial stake of the dominant shareholder. These empirical complementarities in shareholding support the hypothesis that employee stock ownership cumulates itself with the stake of the controlling shareholder.

The theoretical attempt to cross, on the one hand, the economic logics of incentive and creation of value, and, on the other hand, the political logic of control, is relatively recent in the literature. The "Law and Finance" approach with the important work of La Porta, Lopez de Silanes, Shleifer and Vishny (1998) propose a first set of answers. They point out that the major agency conflict in the firm develops between the dominant shareholder and the other outside investors. The long-term logic for the maintenance of control is the access to private benefits; so control has an economic value (cf. Shleifer and Vishny, 1986, Zingales, 1995, La Porta et al., 1999, Faccio and Lang, 2001, Dyck and Zingales, 2004). The given answers are essentially legal ones: rules or regulations, and their enforcement through outside control authorities. This approach is based on an exogenous and deterministic relation from the law to finance. The political logic within the group of control, the mechanisms of inside regulation through internal contracts and auto-regulation of behaviors are not privileged.

Since Jensen and Meckling (1976), the contractual nature of the relationship between the different stakeholders who contribute within the firm to the creation of value has been highlighted. However, there are only a limited number of analyses on the relationship between the control of the firm and the nature of employees' contracts. Garvey and Gaston (1997), as Shleifer and Summers (1998), show that a takeover introduces a change in the implicit contract between managers and employees. However, these two studies are based on the a priori idea that the ruling managers do have an interest in maintaining the labor contract of the employees, and that the initiator of the takeover is interested in canceling it. Gorton and 
Schmidt (2000) analyze the German context of co-management between employees and shareholders, and Gilson and Roe (1999) the Japanese long life employment system. Others authors look at the situation of companies held by their employees (Hansmann, 1996). Chemla et al. (2004) pay attention to the contractual clauses of the agreements inside the group of shareholders to maintain the control. Beside those mentioned, there are only few works on the political logic of substitution of shareholder by executives using a leverage of control which moreover is crossed with an economic incentive approach.

The theory of incentive focuses on the optimal efforts made by managers or employees in an economic logic of shareholders' value maximization. The literature is particularly developed, with the introduction of asymmetry of information, risk aversion or more complex schemes of payment. Holmstrom and Milgrom (1994) enlarge the incentive analysis to workers of the firm and introduced performance incentives and workers' ownership of assets. An approach in term of joint equilibrium contracts makes things more complex if we introduce asymmetries of information. The possibility of a dilution, when awarding discounted stock options, is taken in account by shareholders who optimally set a contract aiming at creating an additional cash flow resulting from the managers' efforts. Martin and Thomas (2003) show that the positive relationship induced by stock options turns negative for shareholders if we take in account the dilutive consequences of massive issues of stocks. Other forms of incentive contracts are developed in the employee stock ownership plans framework. For instance, a model of optimal incentive contracts is developed by Desbrières (1997b) or La Bruslerie and Deffains (2003). Heinrich (2000) analyses the incentive theory applied to managers in a firm with a controlling group of shareholders. With an asymmetry of information on the real effort function of the managers, the existence of cost of monitoring will condition the optimal percentage of ownership by the controlling group.

The global hypothesis of incentive places itself in a clear logic of economic optimization of shareholders' value. The crossed analysis on the relation between the economic optimal contracts and the "political" management of the control of the firm are relatively uncommon. Pagano and Volpin $(2002,2005)$ analyze the role of employees helping the controlling group of shareholders in the context of a hostile takeover. Their model refers to the incentive contracts by looking at the possibility of setting up long term protective labor contracts for the employees or to award stock purchasing plans. They also acknowledge the existence of private benefits of control and introduce the idea of «white squire», i.e. employees become 
allied to the managers and the controlling shareholders to defend the firm under attack. Their model takes in account an information asymmetry, but it is developed only in a context of a defense against a takeover threat. The positive economic effects of the incentive contracts awarded to the employees are explicitly ignored in their model.

Only a few numbers of studies were devoted to the enlarged diffusion of stock options in the firm, apart those privileging a given institutional approach or a link with strategically important events. Dunford et al. (2001) consider that it is not possible to set up a direct relation between the employees' individual performance and the firm's profitability. Few employees (and all the more, shareholders who have less information) can see a direct link between their efforts and the stock price movements in the market. This encourages moral hazard and opportunism in individual behaviors. Questioning a sample of executives in firms, Dunford et al. show that the perception of a direct link is positively related to the situation of the executive in the hierarchy. High executives are more involved and stimulated than others. We find again the Hall and Murphy's idea to limit the diffusion of stock options plans to key executives in the firm. Conversely, the theories which are justifying enlarged stock options plans result from human resources management concepts. The first one states that the absence of a direct link between the employees' performance and the profitability of the firm is not true in firms where there are team works and where co-operation is the norm. Individual opportunist behaviors are then limited by social pressure. This is particularly true in small firms, in those employing people with a strong individual creation power and those in the «New economy» and technology sectors. In the US, Sesil et al. (2002) identified firms awarding stock options on broad basis plans, particularly in the «New Economy ${ }^{4}$. They show that broadening stock options to employees has a superior incentive effect and creates more value. Another explanation for enlarged stock option plans is the sorting and signaling effects for employees outside the firm and wishing to apply for a job. In the labor market, employees identify the unambiguous signal of an individual compensation scheme more oriented toward performance. The firm will attract those who are aware of their individual ability and risk neutral (Oyer et al., 2004). A third explanation for broad issues of stock options is the retention hypothesis. Firms will tend to settle employees within the firm by increasing for them the cost to leave (Oyer, 2003).

The managerial power hypothesis offers a new approach to understand the process leading to jointly agreed stock option contract, which is not the optimal contract imposed by the 
standard incentive theory that gives the bargaining power to shareholders. The "managerial power" approach of Bebchuk and Fried (2003) underlines that the agents have enough power to set their own pay. Choe ( 2003) or Ryan and Wiggins (2004) emphasize the importance of a bargaining process in designing the compensation scheme in a firm. The "managerial power approach" insists on the rent-seeking behavior of managers. They interfere in the design of their compensation schemes (Hall and Liebman, 1998; Bertrand and Mullainathan, 2001; Bebchuk et al., 2002; Jensen and Murphy, 2004). The idea that an informal or implicit negotiation process develops within a framework of asymmetry of information has been highlighted by Bebchuk and Fried (2003). Contract setting mechanism has also been analyzed by Choe (2003) or La Bruslerie and Deffains-Crapsky (2008) with regard to the negotiation of stock option plans plans. The managerial self-dealing hypothesis has been documented by Sautner and Weber (2006). Considering European firms, they show that firms with weak corporate governance and powerful managers have designed stock option programs favorable to executives.

Few papers cross the analysis of stock award to both managers and executives, on one side, and the management of the controlling group, on the other side. To set the way to a coalition contract, we need to complete the traditional incentive theory with a hypothesis of political optimization. Our model of leverage of control develops in the context of economic rationale for a dominant shareholder to give stocks to managers and employees and to dilute his investment. However, the diffusion of stocks to employees, of which efforts are weakly productive, has to be explained. Traditionally the effort function of the managers is viewed as more productive than the one of the other employees. This is due to the difficulty of setting a direct link between the additional effort of a given executive or employee and the increase of the whole profit of the firm.

\section{2-The diffusion of stocks to incentivized employees}

The model is developed in the context of the "normal" life of the firm without any particular contest for the power while we explicitly take in account the effect of incentive contracts in the creation of economic value. The best stimulation of managers, executives and employees is a traditional and permanent economic goal for the controlling shareholder, as well as locking the "political" control over the firm. We want to cross the economic legitimacy of 
value-oriented decisions by the group of control with the political logic of partial substitution of the controlling shareholder by managers and executives. Collusion will help the enlarged dominant group to preserve the rent of control. The possibility for a third party (as a hostile raider) to break the collusion still exists between managers and dominant shareholder as it exists among a controlling group of shareholders. By considering the normal life of the firm, this possibility is still an exogenous threat for the dominant group. We will analyze alliance within the initial controlling shareholder by looking at a partial substitution of the initial shareholder by partners who are awarded new stocks though an ownership plan. So, we start by considering a situation where a dominant shareholder already has control over the firm. Even if a possibility he/she can be challenged by a third party exists before, the probability of a takeover is not modified by the new structure of the dominant controlling group.

The economic problem of the diffusion of stocks through stock awarding plans (or stock option plans) within the firm is the one of the optimal level of diffusion according the different functions of efforts of the involved actors. The search of leverage in control by a mechanism of substitution is simple: the controlling shareholder aims at a lower concentration of his wealth in the firm but still wants to exercise the control through a "political" collusion with new partners in the controlling group and wants to appropriate private benefits. From a portfolio perspective, he/she will profit from a better diversification of his wealth because his financial investment in the firm supports a specific risk premium due to concentration. The released amount of cash can be invested with a better diversification profit in the market. The political desire of politically managing the controlling group results first from a portfolio motivation. That one is permanent; we do not need to refer to a specific threat of takeover. Even if, for instance, a family group owns more than $50 \%$ of the capital, an interest in opening the control exists to allow some members to cash their investment in the firm. The controlling shareholder is supposed well settled. As a constraint, the setting of a coalition contract with others future shareholders should not lead to the loss of control by the new controlling group. Maintenance of control by a restructured group of shareholders is necessary to avoid a possible takeover. Managing the collusion, the dominant shareholder seeks to preserve the larger part of his private benefits while lowering his financial participation through leverage of control. The concept of leverage of control means that this goal is achieved costlessly if stock ownership goes from the controlling shareholder to managers and employees forming a coalition with him. The alliance with managers or executives into an enlarged group of control implies sharing the private benefits and more 
globally implies the negotiation of an implicit coalition contract. The demand for maintenance of control and political collusion by the controlling shareholder is well explained by the existence of private benefits. We have to justify a possible offer of political alliance by managers and others executives. They are interested in the possibility to share a part of these private benefits and to "entrench". If nothing more than a stock ownership is offered, managers and others executives will act as simple outside shareholders and not become allied of the dominant shareholder. Moreover, suffering from concentration of both their human and financial capital in the firm, they will ask a better reward and/or a part of the private benefits. We will identify the sharing of private benefits as a variable of the model.

Here, the executives or the employees who are awarded stocks are considered as allied with the dominant shareholder. The offer of political collusion by the controlling shareholder meets a demand of collusion by the managers/executives. We consider that stimulated managers will become members of the group of control. This is usual in private firms where managers and shareholders belong to the same family group. It will also happen anywhere if only a fraction of the private benefits is given to the new comers in the controlling group. This will explain why they become allied, but not why they stay allied. Once the shares are issued, we do take into account the mechanisms of sharing the private benefits between the controlling shareholder and the new member of the controlling block. That situation will raise problem of jointly agreed sharing of the private benefits of control. We do not consider the problem of stability of the coalition although the equilibrium may be unstable because the sharing of private benefit in an implicit coalition contract will explain the rationale for colluding. The long term loyalty of the new members of the controlling group may be problematic if a takeover bid arises and particularly if the bid price is attractive. However, we consider that the appropriation rate by the controlling group is a perpetuity; it is supposed exogenous. It is constrained by the institutional and legal environment aiming at protecting, or not, private investors. In coalition with managers and executives, these private benefits are shared within the new controlling group. The negotiated percentage $\lambda$ represents the fraction of private benefits retained by the initial controlling shareholder.

It is then interesting to set up incentive mechanisms, either stock option plans, or employee stock ownership plans. These two contracts are different. The first one does not imply an initial cash-flow paid by the beneficiaries and is a pure purchase options. Stock ownership plans entail an initial purchase, often with a discounted price and a subsidy by the employer 
or the government. This cash flow has to be reinvested in the firm projects. We need then a supplementary inside information on the return of the investment projects. On the other side, stock options are only potential stocks without the legal rights linked to ownership, particularly the right to vote. These options can however be immediately transformed in stocks generally after waiting some period of time ${ }^{5}$. We choose hereafter to develop a stylized firm and a stylized contract in a single period model. Among the employees of the firm, we consider only two categories of involved actors: managers (subscript $t$ : top managers) and executives (subscript $m$ : middle management). Each group is composed with homogeneous individuals with identical effort functions expressing their capacity to create an additional cash flow. We define $e(W)$ as the raw cash flow gain directly produced by the contract design that at equilibrium induces a wealth of $W$ for the manager(executive $)^{6}$.Their effort functions $e($.) are strictly increasing with their marginal wealth resulting from the awarded stocks. These functions are different between the two stakeholders groups. The individual efforts will result in a perpetual increase $f()$ in the economic cash flow. What matters here is that the distribution of new shares gives immediate voting rights or easily exercisable voting rights, rebalancing effectively the ownership structure. What imports also is that, at the same time, the setting of the contract develops an immediate creation of value through an effort function. We consider a stock awarding plan in a one period framework. We do not want the initial cash-flow payment of the stocks to appear because it would question the internal rate of return of new investment projects in the firm. Here, a stock awarding plan leads to the issuance of new stocks belonging to managers and executives. In case of stock options, the dominant shareholder considers that the exercise of the options is certain and considers the new structure of ownership. The stock awarding plan can be viewed as a stylized stock purchase plan or stock option plan. It corresponds to a stock ownership plan with either a null purchase price or a long-term deferred payment if the purchase price is not zero ${ }^{7}$. It corresponds also to a stock options contract, the exercise of which is considered as certain and immediate. The stock option contract, where the exercise is certain, is in fact equivalent to a stock ownership plan with no initial cash flow. For instance, this is the case if the stock options are set with a null exercise price or if stock options are immediately exercisable but with a deferred payment of the exercise price. This stylized generic contract is called stock awarding plan and covers features of both stock ownership and stock options plans ${ }^{8}$.

\section{We set:}

$X_{0 \text { : }}$ economic profit of the firm (supposed to be perpetuity) 
$r$ : risk adjusted valuation rate used by the controlling shareholders. It may be greater than the risk adjusted cost of capital in the market because of their wealth under-diversification.

$W_{t}, W_{m}, W_{c}$ :respectively, managers, middle executive and controlling shareholder s' wealth

$N$ : initial number of shares

$k_{t}, k_{m}$ : number of new shares created, respectively, for managers and middle executives, expressed in percentage of the existing number of shares

$f_{t}, f_{m}$ : individual cash flow gain resulting from an individual effort by, respectively, a manager and a middle executive

$n_{t}, n_{m}$ : numbers of managers and executives involved in incentive contracts

$\alpha$ : share of capital belonging to the initially controlling shareholder

$s$ : share of the economic profit directly appropriated by the controlling group.

$\lambda$ : part of the private benefits retained by the initial controlling investors. Managers and others executives will receive $(1-\lambda) \%$ of the private benefits.

We introduce an asymmetry of information: the controlling shareholder does not know with certainty the shape of the individual effort function of the managers and the executives and the resulting increase in cash flow. Individual efforts results in an increase in cash flow $e($. ensuing from stimulated managers or executives. The slope of effort functions of both managers $t$ and executives will depend on the utility of their additional wealth, here $W$. Their utility is strictly increasing with wealth and their effort too. Increases in cash flow come from best efforts, productivity improvement or better decisions. However, economic uncertainty makes the size of the increase in cash flow not deterministic but uncertain even to the managers and executives. They are risk averse in setting their equilibrium effort because they bear an economic uncertainty on the final productivity output of their best efforts. We have:

$$
\tilde{e}(.)=\tilde{e}\left(W_{m, t}\right)=e\left(W_{m, t}\right)+\varepsilon_{m, t}
$$

with $\varepsilon_{m, \mathrm{t}}$ a white noise with standard deviation $\sigma_{m, t}$. We stipulate that the incentive result, i.e. the individual gain of cash flow $e($.$) is increasing with wealth (may be at a decreasing pace).$ The firm profits from an increase in cash-flow but supports some new costs. The managers' efforts are less and less productive, monitoring costs appears. The cost function is $c($.$) . The$ cash-flow increase is a function of both the individual effort function and a cost function linked to the manager(executive)'s increase in wealth, such that $f()=e()-.c($.$) . Any$ functional form $f($.) may be a good candidate, but we want an incentive optimum to exist from the shareholder's point of view. It leads to an optimal economic incentive of managers and 
executives whose action converges to the optimum finite effort. This individual increase cash flow shows a maximum which means that at a certain point the incentive efforts are balanced by negative externalities. The negative cost function is usually set quadratic in the literature. What is important is not the level, but the slope of the cash flow gain function $f($.$) and many$ functional form could have been accepted leading to the condition of a finite $W^{* 9}$. For a given wealth incentive $W$, the gain of cash flow is assumed to be higher for a manager than for a middle executive: $f_{t}>f_{m}$.

The exercise of the option or stock purchase with a null price is certain from the beneficiaries' point of view. The stimulated managers and executives have superior information to set their effort considering. The outcome of their decision is uncertain and they are risk averse because of the uncertainty on their other economic choices. We consider that the exercise is immediate at the inception of the plan. From the controlling shareholder's side, risk aversion should also be taken in account because he/she faces an uncertain gain in cash flow resulting from the effort functions of the managers or the executives. Moreover, he does not know the effort function which is personal and private information of the managers and the executives and can only forecast it, and the induced monitoring costs, with error. The risk here is to guess how much managers are incentivized in a situation of asymmetry of information. It is linked with the unknown slope of the incentive function. Because the later are insiders in the firm they know how much their effort will increase the cash-flow. In our model, the only uncertainty that the initial controlling shareholder faces is the exact amount of gains in cash flows. The risk-averse initial controlling shareholder only knows with imperfection that effort function. His own optimization calculus is based on a forecasted cash flow gain $f^{*}($.$) . He$ guesses it with a larger random noise $\sigma_{c}>\sigma_{m, t}$. We suppose that both controlling shareholder and managers have an exponential utility function ( $\mu$ : risk aversion coefficient):

$$
U(W)=1-\exp (-\mu W)
$$

\section{3-The setting of a collation with managers}

In this section, we consider that new stocks are only awarded to managers.

\section{1) Situation of the controlling shareholder}

We start from an initial situation of control by the dominant shareholder who has a stake of the capital that is the minimum stake of capital to control the firm, $\alpha_{0}{ }^{10}$. There are $k . N$ new 
shares issued toward the managers and the initially controlling shareholder has $\alpha . N$ shares. The initial stake has to be optimized. We want to know the new optimal participation rate $\alpha^{*}$ for the dominant shareholder after the issue of the stock option plan. Then, considering the new controlling group composed by the dominant shareholder and the managers, the held share of capital will be: $\left(\alpha+k_{t}\right) /\left(1+k_{t}\right)$. The initially controlling shareholder forecasts the unknown individual gain of effort $f^{*}$ made by each manager with a random noise $\varepsilon$. This one has a zero mean and a standard deviation, $\sigma_{c}$.

$$
\tilde{f}_{t}(.)=f_{t} *(.)+\widetilde{\mathcal{E}}_{c}
$$

The expected value of the individual expected cash flow is then unbiased: $E(\varepsilon)=0$. The dominant shareholder's wealth before the stock awarding plan is: $W_{c}=\frac{X_{0} s+\alpha_{0} X_{0}(1-s)}{r}$. After awarding stocks, the controlling shareholder holds a new stake $\alpha$ which need to be optimized. This new stake generates profit which adds to the fraction $\lambda$ of private benefits he appropriates. His/her wealth also increased because he/she sold a fraction $\left(\alpha_{0^{-}} \alpha\right)$ of his/her initial stake just before awarding new stocks to managers ${ }^{11}$. It becomes:

$$
\tilde{W}_{c}=\frac{\left(X_{0}+n_{t} \tilde{f}_{t}\right) s \lambda}{r}+\frac{\alpha}{\left(1+k_{t}\right)} \frac{\left(X_{0}+n_{t} \tilde{f}_{t}\right)(1-s)}{r}+\frac{\left(\alpha_{0}-\alpha\right) X_{0}(1-s)}{r}
$$

His gain compared with his initial wealth is:

$$
\tilde{G}_{c}=\frac{1}{\left(1+k_{t}\right) r}\left[n_{t} \tilde{f}_{t} s \lambda(1+k)-X_{0} s(1-\lambda)\left(1+k_{t}\right)-\alpha X_{0}(1-s) k_{t}+\alpha n_{t} \tilde{f}_{t}(1-s)\right]
$$

The dominant shareholder is risk averse and considers the certainty equivalent $C E$ of his uncertain increase in wealth:

$$
\begin{gathered}
C E=\frac{1}{\left(1+k_{t}\right) r}\left[\begin{array}{l}
n_{t} f_{t} *(s \lambda(1+k)+\alpha(1-s)) \\
-X_{0} s(1-\lambda)(1+k)-\alpha X_{0}(1-s) k_{t}
\end{array}\right] \\
-\frac{1}{2} \mu \frac{[s \lambda \cdot(1+k)+\alpha(1-s)]^{2}}{\left(1+k_{t}\right)^{2} r^{2}} n_{t}^{2} \sigma_{c}^{2}
\end{gathered}
$$

A participation constraint (PC) should be set for the controlling shareholder. It outlines that he/she is involved only if a net creation of value compensates the dilution of the economic cash flow and the risk they suffer. The condition for an additional certainty equivalent positive value results from (6). The expected gain in cash-flow ensuing from managers' efforts should respect the condition:

$$
n_{t} f_{t}^{*}>\frac{X_{0}\left(s(1-\lambda)\left(1+k_{t}\right)+\alpha(1-s) k_{t}\right)}{s \lambda\left(1+k_{t}\right)+\alpha(1-s)}+\frac{1}{2} \mu \frac{s \lambda\left(1+k_{t}\right)+\alpha(1-s)}{\left(1+k_{t}\right) r} n_{t}^{2} \sigma_{c}^{2}
$$


This condition collapses into $n_{t} f_{t}^{*}>k_{t} X_{0}+\frac{1}{2} \mu \frac{\alpha}{\left(1+k_{t}\right) r} n_{t}^{2} \sigma_{c}^{2}$ only if $s$ is null, i.e. if there is no private appropriation.

Looking at relation (6) and setting the $C E$ derivative versus $\alpha$ to zero in order to set the first order condition, we get the optimal ownership for the dominant shareholder:

$$
\alpha^{*}=\frac{n_{t} f_{t}^{*}-k_{t} X_{0}-s \lambda\left(\frac{1}{r}\right) \mu n_{t}^{2} \sigma_{c}^{2}}{\mu \cdot n_{t}^{2} \sigma_{c}^{2}(1-s)}\left(1+k_{t}\right) r
$$

The derivative of the optimal ownership for the dominant shareholder (i.e. eq. 7) versus $k$ shows a possible substitution in capital between the controlling shareholder and the managers:

$$
\frac{d \alpha^{*}}{d k_{t}}=\operatorname{sgn}\left[-2 k_{t} X_{0}+\left(n_{t} f_{t} *-X_{0}\right)-s \lambda\left(\frac{1}{r}\right) \mu n_{t}^{2} \sigma_{c}^{2}\right]
$$

The sign of (8) is a priori undetermined. Three terms of (8) out of four are negative. Compared with a situation without private benefits we remark that the sign of (8) is less negative because the last term between brackets vanishes. Moreover, in most cases, the size of the current economic profit $X_{0}$ compared to the additional cash-flow $n_{t} f_{t} *$ lets envisage a negative sign. The variable $\alpha^{*}$ is a quadratic function of $k$. It gives the locus of ownership rates from the dominant shareholder according the opening of capital to the managers. The equation (7) has two roots in the plane $\left(k, \alpha^{*}\right)$. One is negative $(k=-1)$ and is meaningless. The other root is $k=\left[n_{t} f_{t} *-s \lambda\left(\frac{1}{r}\right) \mu n_{t}^{2} \sigma_{c}^{2}\right] / X_{0}$; it gives a positive intercept on the $\mathrm{x}$-axis. We eliminate possibilities such that $n_{t} f_{t}^{*}<s \lambda\left(\frac{1}{r}\right) \mu n_{t}^{2} \sigma_{c}^{2} k$. The curve $\alpha^{*}$ shows a maximum value at point $k=n_{t} f_{t} *-X_{0}-s \lambda\left(\frac{1}{r}\right) \mu n_{t}^{2} \sigma_{c}^{2} / 2 X_{0}$.

For stock awarding plans of which gains of effort are relatively low compared to the economic profit of the firm (i.e. giving a negative sign to equation (8), or more largely if $n_{t} f_{t}^{*}<X_{0}$ ), the relation between $\alpha^{*}$ and $\mathrm{k}$ is strictly decreasing. We are in an economic logic of substitution of the controlling shareholder by managers. The more the dominant shareholder opens the firm's capital, the more he suffers from a certain dilution of the economic profit and the more he is exposed to the risk of an uncertain future profitability because he forecasts with 
noise a more important part of the future global cash flow. The dominant shareholder is then led to reduce his participation.

From equation (7), for $k=0$, and after some manipulation, we get: $\alpha^{* 0}=\frac{f_{t}^{*} r}{\mu n_{t} \sigma_{c}^{2}(1-s)}-\frac{s \lambda}{(1-s)}$. In the same way, for $\alpha=0$, we have: $k=\left[n_{t} f_{t}^{*}-s \lambda\left(\frac{1}{r}\right) \mu n_{t}^{2} \sigma_{c}^{2}\right] / X_{0}$. In this last situation, the initially controlling shareholder disappears. Then managers have a share of capital in percentage relatively to $N$ that is lower or equal to the ratio of the gain in cash flow produced by their effort divided by the current economic profit of the firm. Looking at figure 1, the incentive curve AC of the optimal stock awarding plans is decreasing between the point $\mathrm{A}$ defined by $\alpha^{*^{0}}$ and the point $\mathrm{C}$ where $k=n_{t} f_{t}^{*}-s \lambda\left(\frac{1}{r}\right) \mu n_{t}^{2} \sigma_{c}^{2} / X_{0}$.

Proposition 1 : For the sufficient condition $n_{t} f_{t}^{*}<X_{0}\left(1+2 k_{t}\right)$, the derivative $d \alpha / d k$ is negative.

It means that setting an optimal incentive for managers leads to a negative relation between the optimal share of capital held by the initially dominant shareholder and the share of capital issued toward the managers. This negative relation will initiate an economic logic of incentive allowing a substitution effect of capital ownership within the controlling group. Ceteris paribus, a context of appropriation of private benefit by the controlling shareholder will help to make $d \alpha / d k$ more negative (see eq. 8). It adds an economic motivation to a substitution in stock ownership between colluding parties.

If we can identify a rationale of substitution in the firm's capital between dominant shareholders and managers, does that economic logic meet the political logic of control? The reduction of the under-diversification cost for the controlling shareholder and the perspective of sharing a part of the private benefits for the new shareholders may explain a rationale of substitution in the capital held by the dominant shareholder with the shares awarded to the managers. Then, we are in a setting of a political collusion with well-stimulated managers who become members of the controlling group. The control will be maintained by a group composed with the dominant shareholder and well-stimulated managers becoming shareholders through a stock awarding plan. The condition for control (CC) is that a decrease 
of the share $\alpha$ of the dominant investor should not entail a loss of control by the controlling group, knowing that the initial control threshold is $\alpha_{0}$ :

$$
\frac{\alpha^{*}+k_{t}}{1+k_{t}} \geq \alpha_{0}
$$

That condition results in a negatively sloped line defining a sub-space in the plane $(k, \alpha)$ :

$$
\alpha^{*}>\alpha_{0}-k_{t}\left(1-\alpha_{0}\right)
$$

A "condition of control" is introduced in the model expressing a relationship between the share of capital belonging to the initial controlling shareholder and the number of new shares created by the ownership plan, where the level of control remains constant. This defines an "iso-control" border line. The line corresponding to a coalition setting and a shared control situation; it cuts the $\mathrm{x}$-axis at point $\alpha_{0} /\left(1-\alpha_{0}\right)$ and the $\mathrm{y}$-axis at point $\alpha_{0}$. Equation (7) gives a decreasing curve (1) in the plane $\left(k, \alpha^{*}\right)$ which corresponds to the locus of economically optimal stock awarding plans. Incentive effects are described as an "iso-wealth" line for the controlling shareholder in the space of ownership shares of controlling shareholders and size of the ownership plan.

We will consider four cases. In the first two we consider situations where the initial control threshold is above the actual stake of capital which is economically justified: $\alpha_{0}>\frac{f_{t}^{*} r}{\mu n_{t} \sigma_{c}^{2}(1-s)}-\frac{s \lambda}{(1-s)}$. The stake of capital of the initial controlling shareholder is set equal to $\alpha_{0}$. That starting situation does clearly lead to develop an economically rationale of managers' incentive by opening the capital without political alliance. The opening of capital may nevertheless bring interesting perspectives if a large substitution effect develops in a new coalition group and if a double economic and political justification appears at some point. This is not always the case. In the last two cases, we consider that the reverse is true (i.e. $\alpha_{0}$ below the initial starting point to develop economically an incentive), it means that the stake of the initial controlling shareholder is not in itself enough to initiate a rationale of economic incentive. He should consider at the same time awarding shares to managers in a rationale of political alliance. The four different cases are illustrated in figure 1 and explained below.

a) If, at the same time, $\frac{\alpha_{0}}{\left(1-\alpha_{0}\right)}>n_{t} f_{t} *-s \lambda\left(\frac{1}{r}\right) \mu n_{t}{ }^{2} \sigma_{c}^{2} / X_{0}$, the line of control (a) is above the curve of optimal economic incentive stock awarding contract (1). The political logic of holding control precludes to lower too much the stake of capital 
held by the new shareholder coalition. There are no joint economic and political solutions.

b) If $\alpha_{0}>\frac{f_{t}^{*} r}{\mu n_{t} \sigma_{c}^{2}(1-s)}-\frac{s \lambda}{(1-s)}$ and $\frac{\alpha_{0}}{\left(1-\alpha_{0}\right)}<n_{t} f_{t}^{*}-s \lambda\left(\frac{1}{r}\right) \mu n_{t}^{2} \sigma_{c}^{2} / X_{0}$, the line of control (b) also cuts the curve of stock awarding optimal plans. Only the segment EC corresponds to the admissible choices. This segment implies everywhere a partial substitution of the dominant shareholder by the managers in the controlling group.

c) If $\alpha_{0}<\frac{f_{t}^{*} r}{\mu n_{t} \sigma_{c}^{2}(1-s)}-\frac{s \lambda}{(1-s)}$ and $\frac{\alpha_{0}}{\left(1-\alpha_{0}\right)}>n_{t} f_{t}^{*}-s \lambda\left(\frac{1}{r}\right) \mu n_{t}{ }^{2} \sigma_{c}^{2} / X_{0}$, the line of control (c) cuts the curve of the stock option optimal plans. The domain of the incentive stock options is limited first to the segment AD of the curve. A choice taken on the segment DC does not allow satisfying the condition of joint control. The segment $\mathrm{AB}$ may mean an increase of ownership by the dominant shareholder if his initial stake was set at the rational limit of the iso-control line, $\alpha_{0}$. His goal is to reduce his financial participation; so the admissible choices are given by the segment BD.

d) If $\alpha_{0}<\frac{f_{t}^{*} r}{\mu n_{t} \sigma_{c}^{2}(1-s)}-\frac{s \lambda}{(1-s)}$ and $\frac{\alpha_{0}}{\left(1-\alpha_{0}\right)}>n_{t} f_{t} *-s \lambda\left(\frac{1}{r}\right) \mu n_{t}{ }^{2} \sigma_{c}^{2} / X_{0}$, the line of control (d) is always below the iso-wealth contract curve (1). Any optimally incentive solutions are then compatible with the maintenance of a joint control. The optimal incentive of the managers is certain for the values of $k$ located between 0 and the limit point $\mathrm{C}$. Considering the $\mathrm{AB}$ segment of curve, the couple of values of the choice between the opening of the capital and the stake of the dominant shareholder implies an ownership above $\alpha_{0}$. It would mean an increase of his financial investment in the firm. Conversely, a choice on the segment $\mathrm{BC}$ entails a decrease in the participation of the initial controlling shareholder in the firm's capital. 


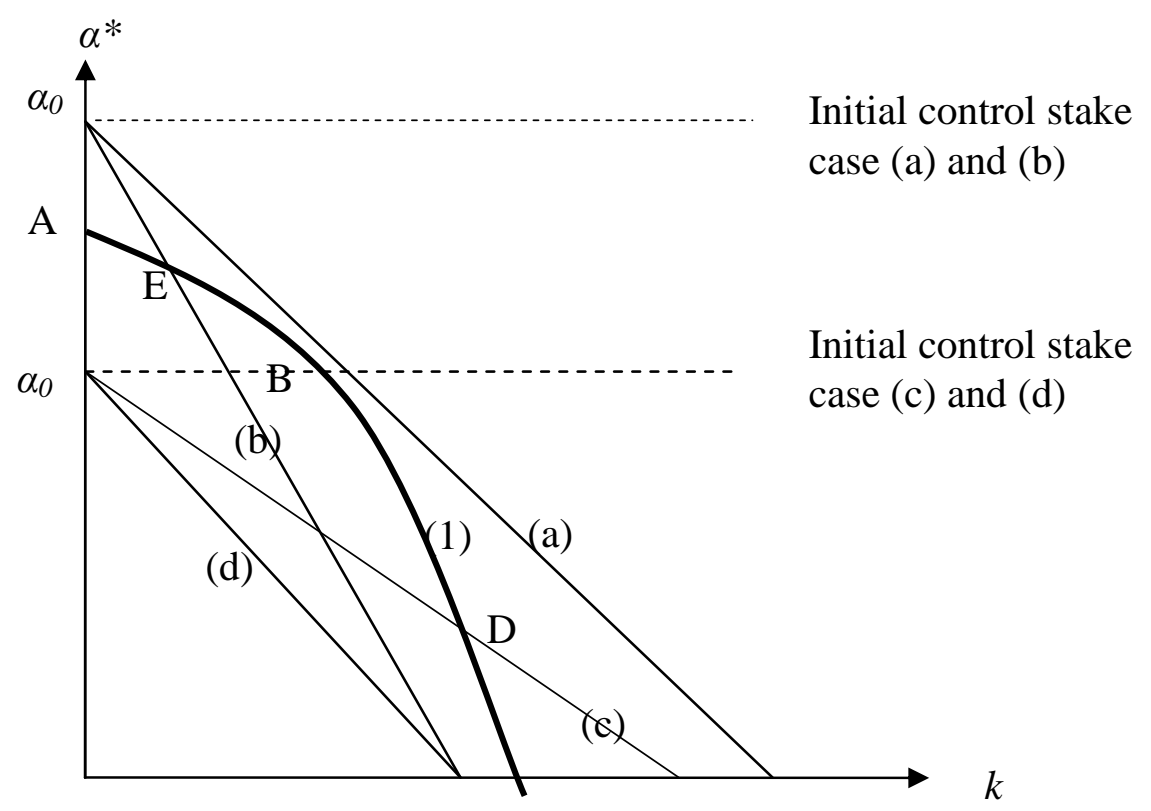

$\mathrm{C}$

Figure 1 - Logic of substitution between dominant shareholder and managers

Considered from the dominant shareholder's point of view, it may exist admissible choices compatible with the maintenance of control if $\alpha_{0}<A$ or if $\alpha_{0} /\left(1-\alpha_{0}\right)<C$ (insuring we are in case (b), (c) or (d)). The respect of one of these conditions is easy if $\alpha_{0}$ is low and/or if $e^{*}$ is high which means a highly productive function of effort. The systematic evidence of a substitution corresponds to the case (d), which means the joint respect of the two inequalities $\alpha_{0}>A$ and $\alpha_{0} /\left(1-\alpha_{0}\right)<C$. We remark that the joint satisfaction is made easy with a high value for $n_{t}$, what means a high diffusion of stock options among numerous managers.

Proposition 2: The distribution of new stocks to a group of optimally incentivized managers (see proposition 1) leads to a partial substitution of the dominant shareholder by the formers in the controlling group. There are cases (cases (b), (c) or (d) in the above developments) where the two logics of economic incentive and political collusion between the dominant shareholder and the managers are strictly coherent and go in the same direction.

\section{2) Managers' wealth after granting stock options}

The global wealth of the managers cumulates a part of private benefits and a stake of capital taking into account an increase in the issued number of shares. They value the perpetuities using the same discounting rate that the controlling shareholder ${ }^{12}$ : 


$$
W_{t}=\frac{\left(X_{0}+n_{t} f\left(e_{t}\right)\right) s\left(1-\lambda_{t}\right)}{r}+\left(\frac{k_{t}}{\left(1+k_{t}\right)}\right) \frac{\left(X_{0}+n_{t} f\left(e_{t}\right)\right)(1-s)}{r}
$$

The managers are risk averse and consider the certainty equivalent $C E$ of their uncertain increase in wealth with a noise $\sigma_{t}$ :

$$
\begin{aligned}
& C E_{t}=\frac{X_{0}}{r}\left[s\left(1-\lambda_{t}\right)+\left(\frac{k_{t}}{\left(1+k_{t}\right)}\right)(1-s)\right]+\frac{n_{t} \cdot f *\left(e_{t}\right)}{r}\left[s\left(1-\lambda_{t}\right)+\left(\frac{k_{t}}{\left(1+k_{t}\right)}\right)(1-s)\right] \\
& -\frac{1}{2} \mu \frac{n_{t}}{r^{2}}\left[s\left(1-\lambda_{t}\right)+\left(\frac{k_{t}}{\left(1+k_{t}\right)}\right)(1-s)\right]^{2} \sigma_{t}^{2}
\end{aligned}
$$

The condition for an additional certainty equivalent positive value results from (6). The managers want to maximize their wealth. They should optimize their individual effort and set $d E C_{t} / d(1-\lambda)$ to zero. Thus from (10) the optimal sharing of the private benefit for the mangers is:

$$
\left(1-\lambda_{t}\right)^{*}=\frac{\frac{X_{0}+n_{t} \cdot f^{*}}{r} s-\mu \frac{n_{t}}{r^{2}}\left[\left(\frac{k_{t}}{\left(1+k_{t}\right)}\right)(1-s) s\right] \sigma_{t}^{2}}{\mu \frac{n_{t}}{r^{2}} s^{2} \sigma_{t}^{2}}
$$

We see from (11) that $\left(1-\lambda_{t}\right)^{*}$ has an inverse relationship with $k_{t}{ }^{13}$. In the managers' demand curve a trade-off appears between awarding stocks and enjoying a part of private benefits. We are in a joint political/economical contract. Negotiating their participation to the new coalition, the managers will ask for a share of private benefits. This parameter is free and depends on the power relationship. In the managerial power approach (Bebchuk et al., 2003) managers will also ask for a certain stake of capital. There exist an infinity of optimal contracts from their point of view in the plane $(k, \lambda)$ given by the curve (11). Private benefit will help an increasing curve to emerge. For managers, it would mean a trade-off relationship between the part of private benefits they earn from belonging to the new controlling group and the stake of awarded capital. Equation (11) can have no admissible solution for $k$. We will hereafter suppose an optimal solution $k_{t}{ }^{*}$ locus exists which is admissible for the managers ${ }^{14}$.

\section{3) Sharing the private benefits and coalition contract}

A joint contract between managers and the initial controlling shareholder to collude in a new controlling group is designed through the two variables $k$ and $\lambda$. From (7), we get the derivate of $\alpha^{*}$ with regard to the shared part of private benefit kept by the initial controlling shareholder: 


$$
\frac{d \alpha^{*}}{d \lambda}=-\frac{s(1+k)}{(1-s)}<0
$$

The percentage of capital withheld by the initial controlling shareholder decreases if the part of private benefits he/she appropriates himself is important. This is a strong incentive to lower his participation stake (reducing the over-investment of his wealth in the firm) and, at the same type, by asking to be paid relatively more with private benefits. The optimal private benefits sharing in the coalition from the initial shareholder point of view is:

$$
\frac{d C E}{d \lambda}=\frac{1}{\left(1+k_{t}\right) \cdot r}\left[n_{t} f_{t}^{*} s(1+k)\right]-\mu \frac{\left[s^{2} \lambda(1+k)^{2}+\alpha(1-s) s(1+k)\right]}{\left(1+k_{t}\right)^{2} r^{2}} n_{t}{ }^{2} \sigma_{c}^{2}
$$

The first order condition is:

$$
\lambda^{*}=\frac{f_{t}^{*} r}{\mu n_{t} \sigma_{c}^{2} s}-\frac{\alpha(1-s)}{s(1+k)}
$$

So, $\operatorname{sgn} \lambda^{*}=\operatorname{sgn}\left(f_{t}^{*} r(1+k)-\alpha(1-s) \mu n_{t} \sigma_{c}^{2}\right)$. Looking at the derivatives, we get $d \lambda * / d k>0$ and $d \lambda * / d s>0$. It means that the initial controlling shareholder is willing to exchange an important share of capital with managers if he/she can get a higher share of private benefits. The negotiation between the managers and the initial controlling shareholders defines a contract of coalition sharing private benefits and defining the relative percentage within the new controlling group.

Finding equilibrium in the coalition group relies on the design of a three variables set: the share of capital held by the initial controlling shareholder, $\alpha$, their appropriated fraction of private benefits, $\lambda$ and the awarded share of capital $k$. The initial controlling shareholder contract setting follows both equations (7) and (14). He/she has a non biased but uncertain view of the individual new cash flow resulting from the incentivized managers, $e_{t} *$. The optimal contract curve for managers is given by relation (11). The later does not refer to $\alpha$, which is not their problem. It defines an increasing curve in the $(k, \lambda)$ plane.

For a given $\alpha^{*}$ value, the initial shareholder curve is increasing. The two curves (11) and (14) converge to different values as $k$ increases and have positive slopes. So they cross and define a unique joint equilibrium coalition contract. To get an admissible solution the contract terms should correspond to values of $\lambda$ between 0 and $100 \%$ and to "reasonable" values for $k$. We call $k_{\max }$ the maximum issue of new shares admissible for the initial shareholder's point of view. He/she accepts to form a coalition but not to be diluted in the new controlling group. 
The ratio of his participation in $\alpha /(\alpha+k)$. He/she has a limited target value for $k$. For instance if he wants to remain a major player in the coalition he will set $k_{\max }=\alpha$. We define a rectangle of admissible values in the $(k, \lambda)$ plane. If the two contract curves cross in the admissible values surface, the setting of an optimal coalition contract is straightforward (see figure 2, Dominant shareholder-case a curve).

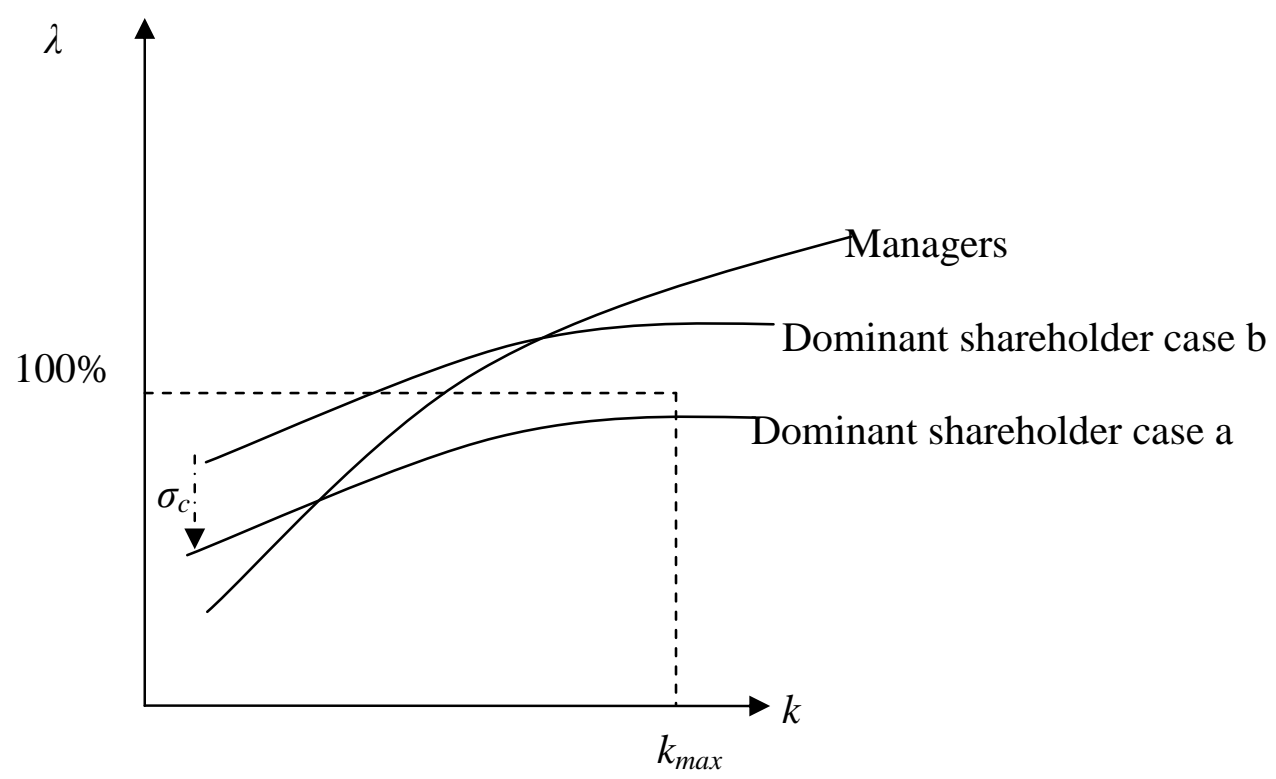

Figure 2 - Setting of the coalition contract

If the two curves cross outside the admissible solutions rectangle (case (b) in Figure 2), the solution of a coalition contract is unstable or uncertain. Incentive may be awarded but no cake sharing is proposed in a new controlling group. No political coalition alliance is agreed. The solution by definition should be located on the managers' curve $\left(f=f^{*}\right.$ in the dominant shareholder's problem). If the curves cross outside the rectangle, a corner solution will hold with $\lambda=1$ (i.e. no private benefits given to managers) and the corresponding (on managers' curve) $k$ offered for incentive reasons. This solution is suboptimal for the dominant shareholder. A stability problem may arise if $k_{\max }$ were so low that the corresponding $\lambda$ on the managers' curve is lower than 1. In this case the large shareholder can propose a contract with $\left(k_{\max }, \lambda\left(k_{\max }\right)\right)$ belonging to the managers' curve (i.e. choose the point where the difference between the two curves is minimized). Obviously if the large shareholder is in control of private benefits and is in the position of excluding the managers from enjoying them, a commitment problem arises because, at $k_{\max }$, his preferred $\lambda_{t}$ is higher than $\left.\lambda\left(k_{\max }\right)\right)$. But this 
will also destroy incentives ${ }^{15}$. Case (b) is economically suboptimal either for the dominant shareholder or the managers.

A convergence is possible within the admissible rectangle through a joint negotiation process. The solution is in the hand of the managers who may give insurances and deliver private information. Asymmetry of information between the two parties results in a white noise for the shareholder who have only a guess $f^{*}$ of the increase in value resulting from the incentive. If the managers gives trustable information on $e$, the standard deviation $\sigma_{c}$ will lower and consecutively the initial shareholder's equilibrium relationship (14) moves down and may cross equation (11) (see Dominant shareholder-case b curve in figure 2). The solution is also in the hand of the dominant shareholder who can play on the variable $n$, i.e. the number of managers who are awarded stocks. If the initial crossing point is above $k_{\max }$, it is possible to limit the number of "happy fews" managers. The managers' curve will then move to the left and may cross within the admissible rectangle solutions. A negotiation process may develop which results in a delivery of private information and/or a political management of the coalition group by setting its size.

This negotiation process within the coalition results in an agreed sharing of the private benefits, $\lambda *$. We remark that the sharing rule has absolutely no reason to follow the relative shareholding proportion. A proportional sharing would mean $\lambda *=\alpha /(\alpha+k)$, i.e. private benefit are shared according the relative proportion of shares in the new dominant group. This proportional sharing rule, if followed, would overdetermine the problem and may results in no optimal joint solution. We see that the existence of private benefits make thing easier to agree an optimal leverage of control. Without any private benefits, the optimal capital stake accepted by managers reduces to an optimal economic incentive problem without any reason for the coalition to remain stable. In a framework of private benefits, an optimal economic incentive of managers and a substitution of ownership in a new controlling group will result in joint optimal values to share the private benefits and to set the percentage of newly issued capital. This defines a coalition contract.

Proposition 3: A process of negotiation based on the delivery of private information by managers and/or a political management of the size of the new controlling group may lead to converge to a unique and joint coalition contract. 
Proposition 4: Compared with a situation without private benefits, the sharing of private benefits in a coalition contract between an initial controlling shareholder and stock awarded managers makes easier the existence of joint and stable coalition equilibrium and helps developing an economical and political logic of leverage of control.

\section{4-The setting of a coalition with managers and executives}

The previous results can be extended if another group of employees, for instance executives, can be economically incentivized and may join a new controlling group.

\section{1) General framework}

We begin by analyzing the general framework of a dominant shareholder looking for collusion with two groups of stimulated employees. His wealth resulting from the joint distribution of stocks to top managers $(t)$ and to middle executives $(m)$ is:

$$
\tilde{W}_{c}=\frac{\left(X_{0}+n_{t} \tilde{f}_{t}+n_{m} \tilde{f}_{m}\right) s \lambda}{r}+\frac{\alpha}{\left(1+k_{t}+k_{m}\right)} \cdot \frac{\left(X_{0}+n_{t} \tilde{f}_{t}+n_{m} \tilde{f}_{m}\right)(1-s)}{r}+\frac{\left(\alpha-\alpha_{0}\right) X_{0}(1-s)}{r}
$$

The increase of wealth compared with the initial situation before the two stock awarding plans is :

$$
\tilde{G}_{c}=\frac{1}{\left(1+k_{t}+k_{m}\right) r}\left[\begin{array}{l}
\left(n_{t} \tilde{f}_{t}+n_{m} \tilde{f}_{m}\right) s \lambda\left(1+k_{t}+k_{m}\right)-X_{0} s(1-\lambda)\left(1+k_{t}+k_{m}\right) \\
-\alpha X_{0}(1-s)\left(k_{t}+k_{m}\right)+\alpha\left(n_{t} \tilde{f}_{t}+n_{m} \tilde{f}_{m}\right)(1-s)
\end{array}\right]
$$

Considered from the dominant shareholder's point of view, the uncertainties resulting from the individual gains of effort from managers and executives are supposed identical and perfectly correlated ${ }^{16}$. This hypothesis avoids separating the random noises $\varepsilon_{c}$ and the standard deviation $\sigma_{\mathrm{c}}$ resulting from the individual gains of effort, with regard to the two categories of actors. The certainty equivalent of the increase of wealth for the dominant shareholder depends on his uncertain information:

$$
\begin{aligned}
& C E=\frac{1}{\left(1+k_{t}+k_{m}\right) r}\left[\begin{array}{l}
\left(n_{t} f_{t} *+n_{m} f_{m}^{*}\right)\left(s . \lambda .\left(1+k_{t}+k_{m}\right)+\alpha(1-s)\right) \\
-X_{0} s(1-\lambda)\left(1+k_{t}+k_{m}\right)-\alpha X_{0}(1-s)\left(k_{t}+k_{m}\right)
\end{array}\right] \\
& -\frac{1}{2} \mu \frac{\left[s \lambda\left(1+k_{t}+k_{m}\right)+\alpha(1-s)\right]^{2}}{\left(1+k_{t}+k_{m}\right)^{2} r^{2}}\left(n_{t}+n_{m}\right)^{2} \sigma_{c}^{2}
\end{aligned}
$$


We find again a participation condition of creation of value, which insures a global incentive from the controlling shareholders to issue a stock awarding plan.

$$
\begin{array}{rl}
n_{t} f_{t}^{*}+n_{m} f_{m} & *>\frac{X_{0}\left(s \cdot(1-\lambda)\left(1+k_{t}+k_{m}\right)+\alpha(1-s)\left(k_{t}+k_{m}\right)\right)}{s \cdot \lambda \cdot\left(1+k_{t}+k_{m}\right)+\alpha(1-s)} \\
& +\frac{1}{2} \cdot \mu \cdot \frac{s \cdot \lambda\left(1+k_{t}+k_{m}\right)+\alpha(1-s)}{\left(1+k_{t}+k_{m}\right) \cdot r}\left(n_{t}+n_{m}\right)^{2} \sigma_{c}^{2}
\end{array}
$$

That incentive constraint is weaker than the one restricted to managers (PC1). It allows getting, on the one hand, a large creation of value at the latter's level and, on the other hand, weakly productive stocks awarding plans at the executives' level. What is important is the global incentive constraint (PC2) to be satisfied. This condition is satisfied, for instance, even if $\left(n_{m} f_{m} *-k_{m} X_{0}\right)$ is negative. This corresponds to the net difference between the value added by the executives in the cash-flow (which may even be negative) and the dilution of the economic initial profit due to the stake of capital awarded to executives. Poorly stimulated, weakly efficient and/or very numerous middle executives can be awarded a relatively important number of stocks compared to their contribution to the creation of cash flow. It can happen in situation where managers have a very efficient effort function and are very productive in term of additional cash flow.

By setting to zero the derivative of equation (17) with regard to $\alpha$, we get the optimal participation rate for the dominant shareholder after issuing the two stock awarding plans:

$$
\alpha^{*}=\frac{\left(n_{t} f_{t}^{*}+n_{m} f_{m}^{*}\right)-\left(k_{t}+k_{m}\right) X_{0}-s \lambda\left(\frac{1}{r}\right) \mu\left(n_{t}+n_{m}\right)^{2} \sigma_{c}^{2}}{\mu .\left(n_{t}+n_{m}\right)^{2} \sigma_{c}^{2}(1-s)}\left(1+k_{t}+k_{m}\right) r
$$

The sign of the derivative of $\alpha^{*}$ with regard to the global awarded percentage of capital, $\left(k_{t}+k_{m}\right)$, is:

$$
\frac{d \alpha^{*}}{d\left(k_{t}+k_{m}\right)}=\operatorname{sgn}\left[-2\left(k_{t}+k_{m}\right) X_{0}+\left(n_{t} f_{t} *+n_{m} f_{m} *-X_{0}\right)-s \lambda\left(\frac{1}{r}\right) \mu\left(n_{t}+n_{m}\right)^{2} \sigma_{c}^{2}\right]
$$

The sign of the relation (19) stays negative if the total gain of cash flow is lower than the magnitude of the three other terms of the RHS of (19) For instance, a total gain of cash flow lower than the initial economic profit of the firm (i.e. $\left.\left(n_{t} f_{t}^{*}+n_{m} f_{m} *\right)<X_{0}\right)$ is a sufficient condition to insure a negative relation between the stake of capital to newcomers in the controlling group and the participation of the initially controlling shareholder. The substitution between $\alpha$ and $\left(k_{t}+k_{m}\right)$ gives a decreasing curve for the optimal economic contracts in the plane $\left(k, \alpha^{*}\right)$, where $k$ is now the total fraction of capital awarded to both 
managers and executives. This curve intercepts the $\mathrm{x}$-axis at the value $\left(k_{t}+k_{m}\right)=\left[n_{t} f_{t}^{*}+n_{m} f_{m} *-s \lambda\left(\frac{1}{r}\right) \mu\left(n_{t}+n_{m}\right)^{2} \sigma_{c}^{2}\right] / X_{0}$. It is located more on the right in the plane $(k, \alpha)$ compared to the situation where the stock option plan was restricted only to managers (if $f_{m}($.$) is positive, i.e. if the efforts made by the executives are at the least$ productive).

The intercept with the $y$-axis is located at:

$$
\alpha_{t+m}^{* 0}=\frac{\left(n_{t} f_{t}^{*}+n_{m} f_{m}^{*}\right) r .}{\mu\left(n_{t}+n_{m}\right)^{2} \sigma_{c}^{2}(1-s)}-\frac{s \lambda}{(1-s)}
$$

If we compare with the intercept in the situation of stock plans only limited to managers, $\alpha{ }_{t^{2}}^{0}=\frac{\left(n_{t} f_{t}^{*}\right) \cdot r .}{\mu \cdot\left(n_{t}\right)^{2} \cdot \sigma^{2} \cdot(1-s)}-\frac{s \cdot \lambda}{(1-s)}$, we can see that $\alpha^{* 0}{ }_{t+m}$ is located below $\alpha^{*{ }^{0}}{ }_{t}$.

Remembering the hypothesis $f_{t}>f_{m}$, we obtain:

$$
\frac{\left(n_{t} f_{t} *+n_{m} f_{m}^{*}\right) r}{\mu\left(n_{t}+n_{m}\right)^{2} \sigma_{c}^{2}}<\frac{\left(n_{t} f_{t} *+n_{m} f_{t}^{*}\right) r}{\mu\left(n_{t}+n_{m}\right)^{2} \sigma_{c}^{2}}=\frac{f_{t}^{*} r}{\mu\left(n_{t}+n_{m}\right) \sigma_{c}^{2}}
$$

For non zero values of $n_{m}$, we have:

$$
\frac{f_{t} * r}{\mu\left(n_{t}+n_{m}\right) \sigma_{c}^{2}}<\frac{f_{t}^{*} r}{\mu \cdot n_{t} \sigma_{c}^{2}}
$$

As a consequence, the curve of incentive stock awarding plans enlarged to both managers and executives always cuts that one only limited to managers (for positive $f_{m}($.$) ). We show that a$ substitution in ownership between the dominant shareholder and executives is effective with enlarged stock awarding plans if the sign of equation (19) is negative. Nevertheless, the economic optimal substitution is less effective for more widely distributed plans. The incentive gains are marginally lower $\left(f_{m}<f_{t}\right)$ and dilution on a larger number of stocks is certain. Moreover, the dominant shareholder is exposed to a more important estimation risk on the future additional cash flow: the uncertainty on the gains of effort resulting from managers and executives cumulates. It follows that the slope of the curve (18) of the optimal stock awarding plans is weaker in the plane $\left(k, \alpha^{*}\right)$.

In the context of collusion between the dominant shareholder and, on the other side, managers and executives in a controlling group, the condition for maintaining the control (CC) is:

$$
\alpha^{*}>\alpha_{0}-\left(k_{t}+k_{m}\right) \cdot\left(1-\alpha_{0}\right)
$$


This inequality gives a border line which position in the plane $\left(k_{t}+k_{m}, \alpha^{*}\right)$ is unchanged compared with the alliance with only managers. The difference is that the former opening of the capital offered to only managers is now split between managers and executives. The maximum value of the opening rate of the capital $\alpha_{0} /\left(1-\alpha_{0}\right)$ will now limit the number of stocks awarded to both managers and executives. Figure 3 shows the new situation of a substitution which, at the same time, is economically stimulating and maintains a control on the firm. The shift of the upper part of the curve below the line of control is a direct function of the diffusion of stocks to the executives, $n_{m}$. Such a situation leads to a systematic substitution of ownership in the controlling group where both the economic logic of incentive and a political leverage of control act in the same direction for the initial dominant shareholder. The enlarged possibilities of choices of optimal stock options plans is given by the segment $\mathrm{AB}$ which replaces the segment $\mathrm{CD}$ of the curve of choices only limited to managers. This extension gives more discretionary power to the dominant shareholder. It is allowed by the existence of positive gains of effort from executives $\left(f_{m}>0\right)$ and by the distribution of options to many stimulated people. From the dominant shareholder's point of view, the logic of a large substitution in ownership both allows the maintenance of the control and can be economically efficient.

We remember that the optimal incentive of managers and executives needs also to satisfy two demand equations similar to (11) which express a desire to get stocks and to participate in the capital. The solution $\left(k_{t}+k_{m}\right)^{o p t}$ has an higher value than the share of capital asked by the only managers, $k_{t}^{\text {opt }}$. The final joint equilibrium is more on the left and corresponds to a larger diffusion of capital to executives and therefore in a logic of substitution, to a lower share of direct ownership $\alpha^{*}$ by the dominant shareholder. 


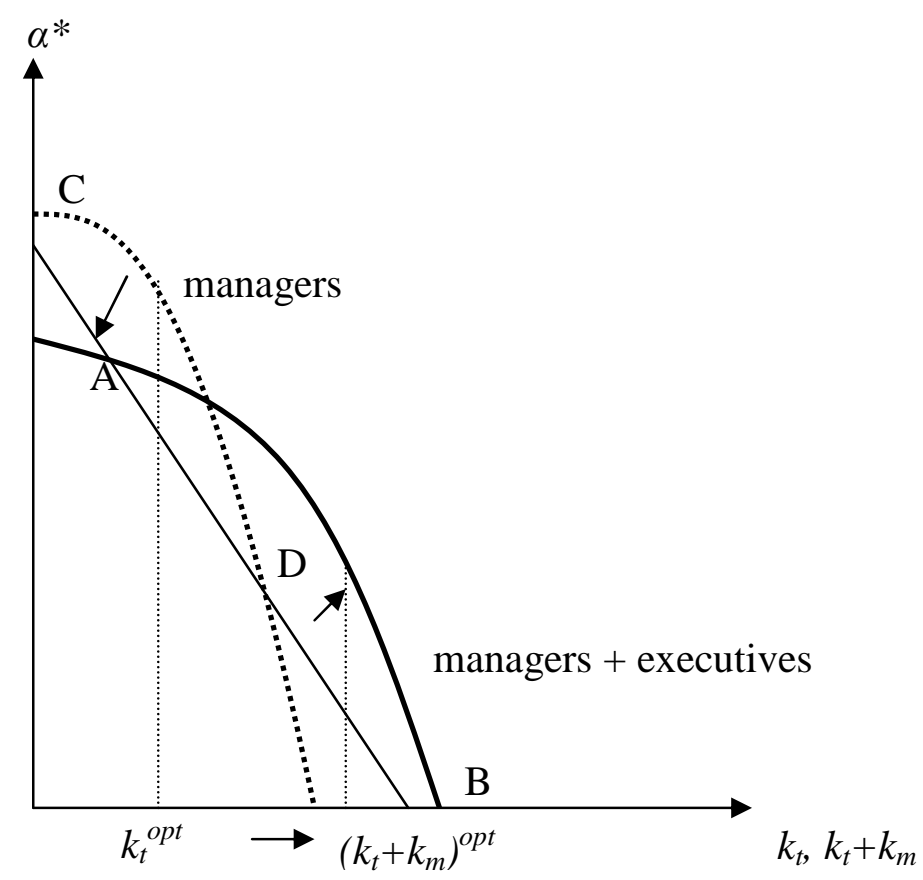

Figure 3 - Substitution equilibrium with stock options limited to managers and opened to managers and executives

Proposition 5: The search of an economic equilibrium with a set of globally efficiently incentivized employees in the firm can be totally compatible with a logic of substitution of ownership in a controlling group even if an enlarged category of beneficiaries whose efforts are weakly productive is involved.

\section{2) Case of executives with inefficient effort functions}

Is there an economic logic to diffuse stock options even if the beneficiaries cannot produce any additional cash flow? This question does not refer only to the situation of non-stimulated executives whose effort function is null, but also to the problem of non-observable effort functions. The difficulty, for the controlling shareholder when setting stock awarding plans, is to make a link between the distribution of stocks and the additional cash flow resulting from the effort of the beneficiaries. If the effort function is not observable, the situation viewed for the controlling shareholder is the same as if the beneficiaries are inefficient.

Here we suppose that, on the average, the dominant shareholder knows that the efforts made by the middle executives are not productive (or not observable) $: E\left[f_{m}().\right]=0$. Maybe some executives can be effectively stimulated and can produce an additional individual cash flow, others are not, and some will entrench because their individual behavior is not observable. 
The average is null. For the dominant shareholder, the individual uncertainty remains with a standard deviation $\sigma_{c}$ around the null expected individual cash flow. The shareholders, when enlarging a stock awarding plan to executives, are then in a situation where their marginal gain is zero, although they support a risk of estimation and a certain dilution. The previous conclusions should be modified because it is now economically useless to set up an enlarged stock awarding plan. The whole curve of incentive stock plans moves downward. The intercept with the $\mathrm{x}$-axis remains identical to the one of the situation of stock awarding plans restricted to only managers, so: $\left(k_{t}+k_{m}\right)=\left[n_{t} f_{t}^{*}-s \lambda\left(\frac{1}{r}\right) \mu \cdot\left(n_{t}+n_{m}\right)^{2} \sigma_{c}^{2}\right] / X_{0}$ (point C, figure 4).

When considering equation (20), the intercept with the y-axis shifts down rapidly because it is an inverse function of the squared value of $n_{m}$. The more the diffusion to inefficient agents is large in the firm, the more it is economically irrational to justify the award to many people. In any case, substitution is weaker. The enlarged diffusion of stocks entails a general dilution of the wealth produced by the managers that depends on the opening rate of the capital $k_{m}$ of which the executives will benefit. The enlarged distribution to inefficient agent creates a windfall profit for those who appropriate a part of the economic profit created by the managers. The economic optimality of these plans is lower for the shareholder. If $n_{m}$ (and thus $k_{m}$ ) is too important, the diffusion is too large and the curve of economically incentive contracts shifts below the line of control. This happens particularly if, beside, we have $\left(k_{t}+k_{m}\right)=\left[n_{t} f_{t}^{*}+n_{m} f_{m} *-s \lambda\left(\frac{1}{r}\right) \mu\left(n_{t}+n_{m}\right)^{2} \sigma_{c}^{2}\right] / X_{0}<\left(\alpha_{0} /\left(1-\alpha_{0}\right)\right)$ (see figure 4). In that situation, we do not get any admissible enlarged stock awarding plan because the entire curve is then located below the control line. If conversely $\left(k_{t}+k_{m}\right)=\left[n_{t} f_{t}^{*}+n_{m} f_{m}^{*}-s \lambda\left(\frac{1}{r}\right) \mu\left(n_{t}+n_{m}\right)^{2} \sigma_{c}^{2}\right] / X_{0}>\left(\alpha_{0} /\left(1-\alpha_{0}\right)\right)$, the intercept with the xaxis is more on the left of the minimum control line. The curve of economically incentive stock option plans cuts the control line in a point which is also located more on the left. Then, it is still justified both economically and in term of control to set up enlarged stock awarding plans, although the goal of a better incentive has no sense for a sub-category of inefficient beneficiaries. The necessary condition is that the other beneficiaries are efficiently stimulated and create important individual gains of cash flow. 
The search of a pure logic of substitution can be to lower the curve of the optimal stock awarding plans which then can easily be located below the initial share of ownership $\alpha_{0}$. Figure 4 shows, for a given demand of plans from the managers, $k_{t}{ }^{*}$, that lowering the curve allows initiating an easier logic of substitution in the group of control. The optimal joint equilibrium (point A) before an enlarged diffusion to the executives entails an increase in the share of capital of the dominant shareholder which is by definition the opposite of the soughtafter substitution. The new curve, below the previous one, leads to the double and coherent logic of economic optimization of incentive and of political optimization of control through leverage. The joint solution given by the point $\mathrm{B}$ is located below the line corresponding to the $\alpha_{0}$ ordinate. It means a decrease in ownership and a leverage of control for the dominant shareholder.

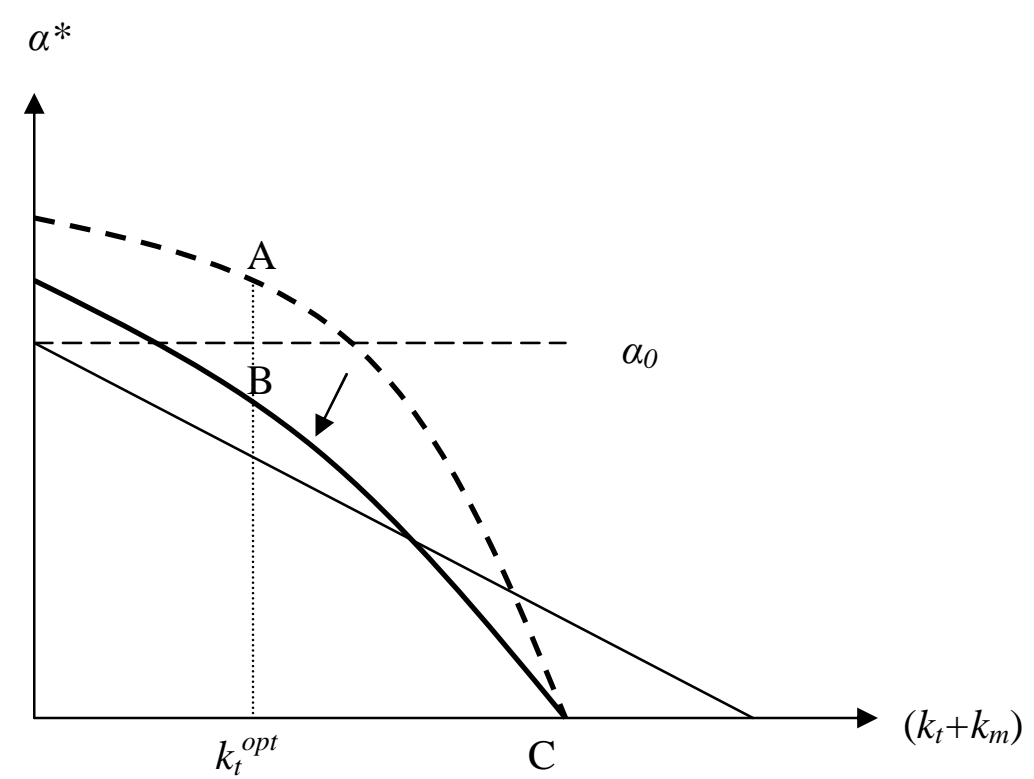

Figure 4 - Situation of executives with inefficient efforts

The research of a pure leverage of control based on a large offer of new stocks to many executives or employees can be justified although they will not be economically incited to create more value. The global economic incentive is weaker, but the first goal for the dominant shareholder is to lower his participation and what matters is that there are enough incited and productive managers to make the logic of substitution of the dominant shareholder economically valid. The incentive condition to be satisfied is then: $\left[n_{t} f_{t} *_{-}\left(k_{t}+k_{m}\right) X_{0}\right]>0$. In that framework, the logic is first a political substitution in the controlling group conditioned by a global economic constraint. 
The difficulty, then, is the allocation of the new stocks between the managers and the executives. The research of an optimal incentive will lead to follow a distribution which best stimulates each ones' efforts. The respect of the equation (5) allows identifying the asked optimal share of capital according to the marginal effort. If $f_{m}=0$, the share of capital economically justified for the executives, $k_{m}$, should be zero. It follows that all the shares awarded in an enlarged stock awarding plan should be allocated to the managers who are creating all the additional value. We are then in a contradiction between the economic logic of best incentive, which lead to exclude the executives from the award of stocks, and the political logic of a large substitution by a strong leverage of control. If $k_{m}$ is not zero, the managers are not in a situation corresponding to their optimized effort function and resulting an additional individual cash flow $f_{t}^{*}$. With $k_{t}<k_{t}^{\text {opt }}$, they produce a gain $f_{t}<f_{t}^{*}$. The point $\mathrm{C}$ in figure 4 (equal to $n_{t} f_{t} X_{0}$ ) will move on the left and can lead easily to a shift of the curve of the sub-optimal contracts below the control line. As a consequence, a non zero value for $k_{m}$, in a situation of inefficient executives, makes more difficult the achievement of a logic of substitution by an enlarged plan of stock options. There, the decision for the dominant shareholder is a trade-off between economic and political logics which do not lead to compatible and optimal choices. His decision will be economically non-optimal for any significant allocation of new stocks to inefficient executives.

Is it possible to develop a political logic of substitution in ownership with non cash flow productive or stimulated executives? We can push further the argument for a political logic of substitution through an enlarged stock awarding plan given to inefficient executives (or employees). The idea is to optimize the trade-off between the political goal and the economic optimality. The dominant shareholder can promote such an enlarged plan while he perfectly knows that the distribution of new stocks will not create any additional observable cash flow (an additional cash flow is possible but it cannot be attributed to the executives' efforts). He is then in a context of certainty, with no incentive behavior from the supposedly inefficient effort of executives. The dominant shareholder knows that the executives will create no additional cash flow $f_{m}()=.0^{17}$. The incentive is true for the managers and false for the executives. Then, the dominant shareholder is not exposed to any estimation risk $\sigma$ about the latter because he/she has no doubt on their behavior ${ }^{18}$. He privileges cynicism. He refuses to investigate, or to explicit, the creation of value from middle executives and employees even if it is non-null. The cost to reveal individual performance in a team or in a department may be 
high enough to justify such an attitude. The only remaining risk for the dominant shareholder results from the effort function of the stimulated managers. The certainty equivalent of the shareholder's wealth (17) simplifies. Particularly, we remark that the risk premium is lower: in that sense, cynicism is rational here because it improves the welfare of the dominant shareholder in a situation of non-efficient (or non identifiable) efforts from the executives.

$$
\begin{aligned}
& C E=\frac{1}{\left(1+k_{t}+k_{m}\right) \cdot r}\left[\begin{array}{l}
\left(n_{t} f_{t}^{*}\right)\left(s \cdot \lambda \cdot\left(1+k_{t}+k_{m}\right)+\alpha(1-s)\right) \\
-X_{0} s(1-\lambda)\left(1+k_{t}+k_{m}\right)-\alpha X_{0}(1-s)\left(k_{t}+k_{m}\right)
\end{array}\right] \\
& -\frac{1}{2} \mu \frac{\left[s \lambda\left(1+k_{t}+k_{m}\right)+\alpha(1-s)\right]^{2}}{\left(1+k_{t}+k_{m}\right)^{2} r^{2}}\left(n_{t}\right)^{2} \sigma_{c}^{2}
\end{aligned}
$$

We get:

$$
\alpha^{*}=\frac{\left(n_{t} f_{t}^{*}\right)-\left(k_{t}+k_{m}\right) X_{0}-s \lambda\left(\frac{1}{r}\right) \mu\left(n_{t}\right)^{2} \sigma_{c}^{2}}{\mu\left(n_{t}\right)^{2} \sigma_{c}^{2}(1-s)}\left(1+k_{t}+k_{m}\right) r
$$

Looking at the optimal shareholding for the dominant investor (eq. 22), we see that we are in the same situation as the one limited to only managers (see equation (10)). For the reasons already exposed above, the economic rational allocation of stocks awarding should be only for those with a productive function of effort; then $k_{m}=0$. Any diffusion of stocks to executives will be economically sub-optimal and will weaken the leverage of control ${ }^{19}$.

However, the contradiction between a "political" enlarged diffusion of stocks and the best economical stimulation can be partially raised if we consider in equation (22) that $\alpha^{*}$, the optimal ownership of the initial dominant shareholder, does not refer to the number of executives who are given new stocks. So, the value of $n_{m}$ can be very large. We can then envisage a "political" management of the leverage of control by awarding to the managers a share of the capital very close to the one that leads to their best economic incentive $\left(k_{t} \approx k_{t}{ }^{*}\right)$; the share given to the executives being very small or negligible $\left(k_{m} \approx 0\right)$. In the same time, the beneficiaries will be very numerous. We are led to a symbolic management of stocks distribution in the firm with high $n_{m}$ and low $k_{m}$. At the limit, a generalized distribution of stocks to the firm's employees, but in very small individual quantity, is politically meaningful and economically acceptable.

A symbolic policy of stock awarding in order to create a leverage of control should however be at least compatible with enough productive efforts made by some categories of agents of the firm in order to respect the economic incentive rationale. A purely political coalition with 
everybody implies some welfare costs due to the non-efficient (or non-recognizable) efforts of some categories of employees. They are given a rent which is paid by the shareholder who accepts a dilution and the agents whose efforts are highly productive but not well paid.

The political-economical trade-off seems here to be sub-optimal in term of economic welfare. But, we show that this "cost" can be politically managed and limited. Moreover, we should take in account the fact that political cynicism leads the manager to the same risk premium as in the case of stock awarding limited to only productive managers. This question has important consequences if we consider the problem of observability. May be executives have poorly efficient functions of effort creating a small additional cash flow? Ex post, the firm will only observe a global increase in cash flow. However, it does not have ex ante forecasts of individual performance. If the cost to set up a system of objective individual performance attribution is very high (or impossible), it is worthless to "invest" in the incentive of employees. It is therefore rational to follow a symbolic management of incentive contracts looking for a larger coalition in a new controlling group without departing too much from the economic optimality. The conjunction of the economic rationality of incentive and the political logic of a leverage of control is possible. Even in a situation where some agents have non-productive (or non-observable) functions of effort, it is rational to propose enlarged stock awarding plans. The political and symbolic management of the group of control appears then as the first goal.

The enlarged distribution of new stocks to numerous executives for symbolic individual quantities allows, even if their effort functions are non-productive (or non-observable), to develop a mechanism of leverage of control that remains compatible with the economic incentive of highly productive managers. However, the substitution in ownership develops in a trade-off where the best optimal incentive goal is dominated by the political logic of collusion.

\section{Conclusion}

The research of a leverage of control by awarding new stocks takes place in a double logic of economic creation of value through incentives and of substitution of the initial dominant shareholder by managers and executives. Respecting the global maintenance of control, both the logic of substitution in ownership and the one of best incentive contracts, are strictly 
compatible and push in the same direction. The diffusion of stocks through ownership or options plans to other categories of executives or employees may still respect the coherence between an economic rationale of incentive and a political rationale of substitution. Even if the effort functions of the executives are weakly productive, we showed that a joint equilibrium is still possible. More, even if the effort functions of some agents are not productive (or observable), we pointed out that a political logic of substitution is still rational if two conditions are met. The first one is to follow a symbolic policy of distribution of a very small numbers of stocks to numerous people. The other one is that, globally, it exist a sufficient economic incentive for the highly efficient agents whose effort will create a large additional cash flow. The development of a leverage of control is only possible if the economic incentive is globally productive. This is the basic condition to allow a substitution of the dominant shareholder by managers and executives who are globally well stimulated. If they are not, the dominant shareholder will have to consider a trade-off between economic and political logics.

The substitution and the collusion of the dominant shareholder with managers and executives allow the first to maintain his appropriation of the profit derived from control. The question of sharing the private benefits within the new controlling is addressed. We saw that the controlling shareholder has to abandon a share of the private benefits to managers. A rationale of coalition would address the question of sharing rule equilibrium because ex ante the coalition should be seen as stable by both parties. We highlight that an implicit contract of coalition exists and had admissible designs for both parties.

Different propositions are drawn which can be empirically tested. For instance, the awarding of new stock ownership plans should be crossed with new equilibriums in the structure of the controlling group of the firm. The market reaction should not be the same compared to firms with dispersed ownership. The model can also be improved in further analysis. The first idea should be to take in account a lower expected rate of return used by the dominant shareholder to evaluate the firm. We know that he/she has to pay a specific premium because of his concentration of wealth in the controlled firm. A substitution in ownership (but not in control) will make him profiting from a better diversification. This element adds on the benefits drawn by the controlling shareholder from the operation. Similarly, the managers and executives will use a higher valuation rate to take into account the lower diversification of their human and financial capital. 


\section{References}

Bebchuk L., Fried J., Walker D., 2002, "Managerial power and rent extraction in the design of executive compensation", University of Chicago Law Review, vol. 69, p751-846

Bebchuk L., Fried J., 2003, "Executive compensation as an agency problem", Journal of Economic Perspectives, vol.17, p71-92

Bertrand M., Mullainathan S., 2001, "Do CEOs set their own pay? The ones without principals do", Quarterly Journal of Economics, vol.116 n³, p901-923

Chemla G., Habib M., Ljungqvist A., 2004, “An analysis of shareholders agreements”, WP 2004-9, CEREG, University Paris IX Dauphine, 2004

Choe C., 2003, "Leverage, volatility and executive stock options", Journal of Corporate Finance, vol.9, p591-609

Desbrières P., 1997a, "La participation financière des salaries et ses incidences sur la performance et l'organisation interne de l'entreprise", in G. Charreaux (ed.), Le gouvernement des entreprises, Economica, Paris, p361-395

Desbrières P., 1997b, "Le rôle de l'actionnariat des salariés non-dirigeants dans le système de gouvernement d'entreprise", in G. Charreaux (ed.), Le gouvernement des entreprises, Economica, Paris, p397-417

Dhillon U., Ramirez G., 1994, "Employee ownership and corporate control: An empirical study", Journal of Banking and Finance, vol. 18, p9-26

Dunford B., Boudreau J., Boswell W., 2001, “The dark side of stock options: Downside risk and employee separation", working paper CAHRS, Cornell University

Dyck A., Zingales L., 2004, "Private benefits of control: An international comparison", Journal of Finance, vol. 59, p 537-600

Faccio M., Lang L., Young L., 2001, "Dividends and expropriation", American Economic Review, vol. 91, p54-78

Garvey G., Gaston N., 1997, "A theory of the optimal cost barrier to corporate takeovers", International Economic Review, vol. 38, n³, p657-675

Gilson R., Roe M., 1999, "Lifetime employment labour peace and the evolution of Japanese corporate governance", Columbia Law Review, vol. 99, n5, p508-540

Gorton G., Schmid F., 2000, "Class struggle inside the firm: A study of German codetermination", NBER working paper $\mathrm{n}^{\circ} 7945$, October

Hansmann H., 1996, The ownership of enterprise, Harvard University Press, Cambridge, USA

Hall B., Liebman B., 1998, “Are CEOs really paid like bureaucrats?”, The Quarterly Journal of Economics, volume CXIII, Issue 3.

Hall B., Murphy K., 2002, "Stock options for undiversified executives", Journal of Accounting and Economics, vol.33, p.3-42

Hall B., Murphy K., 2003, "The trouble with stock options", Journal of Economic Perspectives, vol.17, p.49-70

Heinrich R., 2000, "Complementarities in corporate governance, ownership concentration and pecuniary incentives", Kiel working paper n ${ }^{\circ} 968$, Kiel Institute of World Economy

Holderness C.G., 2009, "The myth of diffuse ownership in the United Sates", Review of Financial Studies, vol. 22(4), p.1377-1408

Holmstrom B., Milgrom P., 1994, "The firm as incentive system", American Economic Review, vol.84, n4, p972-991

Jensen M., Meckling W., 1976, "Theory of the firm: managerial behavior, agency costs and ownership structure", Journal of Financial Economics, vol. 3, p305-360

Jensen M., Murphy K., 2004, 'Remuneration: Where we've been, how we got to here, what 
are the problems, and how to fix them", ECGI working paper 44-2004, www.ssrn.com

Karpoff J., Malatesta P., Walking R., 1996, "Corporate governance and shareholders initiatives: Empirical evidence”, Journal of Financial Economics, vol. 42, p365-395

La Bruslerie H. (de), Deffains-Crapsky C., 2003, «Contrat optimal d'actionnariat salarié et asymétries d'information », Revue Finance, vol. 24, décembre, p113-142

La Bruslerie H. (de), Deffains-Crapsky C., 2008, "Information asymmetry, contract design and process of negotiation: The stock option awarding case", Journal of Corporate Finance, vol. 14(2), p73-91

La Porta R., Lopez de Silanes F., Shleifer A., Vishny R., 1998, "Law and finance”, Journal of Political Economy, vol. 106, 1998, p1113-1155

La Porta R., Lopez de Silanes F., Shleifer A., 1999, "Corporate ownership around the world", Journal of Finance, vol. $54 \mathrm{n}^{\circ} 2$, p471-517

La Porta R., Lopez de Silanes F., Shleifer A, Vishny R., 2000, "Investor protection and corporate finance", Journal of Financial Economics, vol. 58, p3-27

Martin K., Thomas R., 2003, "When is enough, enough? Market reaction to highly dilutive stock option plan and the subsequent impact on CEO compensation", Journal of Corporate Finance

Ofek E., Yermack R. W., 2000, "Taking stock: equity bared compensation and the evolution of managerial ownership", Journal of Finance, vol. 54, June

Oyer P., 2003, "Why do Firms Use Incentives That Have No Incentive Effects?" Journal of Finance, vol. 59, n 4 , p. 1619-1650

Oyer P., Schaefer S., 2004, "Why do firms give stock options to all employees?: An empirical examination of alternative theories", NBER, working paper $n^{\circ} 10222$

Pagano M., Volpin P., 2000, "The political economy of corporate governance", CSRF, working paper $\mathrm{n}^{\circ} 29$

Pagano M., Volpin P., 2002, "Managers, workers and corporate control", working paper European Corporate Governance series in Finance $n^{\circ} 01 / 2002$, October 2002, and Journal of Finance, vol.60, $\mathrm{n}^{\circ} 2$, april 2005, p.841sq

Park S., Song M., 1995, "Employee stock ownership plans, firm performance and monitoring by outside blockholders", Financial Management, vol. 24, n ${ }^{\circ}$, pp52-65

Ross S., 2004, "Compensation incentives and the duality of risk aversion and riskiness", Journal of Finance, vol. 59, February, p207-225

Ryan H., Wiggins R., 2004, "Who is in whose pocket? Director compensation, board independence, and barriers to effective monitoring", Journal of Finance, vol. 73, p.497-524

Sautner Z., Weber M., 2006, "Corporate governance and the design of stock option programs", working paper, EFA 2006 Zurich Meetings, www.ssrn.com

Sesil J., Kroumova J., Blasi J., Kruse D., 2002, "Broad based employee stock options in US "New Economy" firms", British Journal of Industrial Relations, vol. 40, n², p273-294

Shleifer A., Summers L., 1998, "Breach of trust in hostile takeovers, in Corporate takeovers: Causes and consequences", edited par A. Auerbach, p33-56, University of Chicago press, Chicago, USA

Shleifer A. Vishny R., 1986, "Large shareholders and corporate control", Journal of Political Economy, vol. 94, p461-488

Trebucq S., 2002, «L'actionnariat salarié dans les entreprises familiales du SBF 250:Un outil de création de valeur? », Cahier de recherche n²002-04, IAE de Bordeaux, Université de Bordeaux IV

Yermack D., 1997, "Good Timing: CEO Stock Option Awards and Company News Announcements", Journal of Finance, vol. 52, p. 449-476

Zingales L., 1995, "What determines the value of corporate votes?", Quarterly Journal of Economy, p1047-1073 
${ }^{1}$ This figure are to be put in the context of an existing bias in favor of a «Broad plan » : they do no request a mandatory agreement of the shareholders' general meeting before launching.

${ }^{2}$ After a maximum outstanding amount of 238 billions USD in 2000 with the NTIC bubble.

${ }^{3}$ Estimation from the National Center on Employee Ownership (NCEO) reported by Hall and Murphy, p7

${ }^{4}$ They used the definition from the NCEO who considers that a stock option plan is broad-based if $50 \%$ of the firm's employees receive stock options, whatever their distribution.

${ }^{5}$ A legal analysis can be developed at this level. Generally, a vesting period exists, for instance, because of tax reasons. But in certain situations, stock options contracts include early exercise possibilities in case of takeover or major events. These clauses of « accelerated vesting » are common for stock options awarded to top managers, particularly in the US.

${ }^{6}$ We acknowledge that the effort function will depend on the structure of the compensation scheme of the managers(executives). Wealth in form of a stock grant will induce a different effort compared to wealth from a fixed payment. Here the stock grant will modify the structure of the compensation package. We develop a marginal approach and assume that the stock grant will not modify the incentive equilibrium designed before.

${ }^{7}$ Zero cost stock awards ("Attribution d'actions gratuites") are common in France because of the unfavourable tax treatment of stock options.

${ }^{8}$ The possibility of a cash settlement can be input easily in the model at least conceptually. If we assume that the cash payment is reinvested at the risk adjusted valuation rate of the firm a cash-flow ensuing from a non zero exercise price can be included in the model. It creates no additional value. Results are basically similar. If we introduce a reinvestment rate for the cash-flow proceeds things are more complicate because it raises a problem of asymmetry of information between the managers and the controlling shareholder (see La Bruslerie and Deffains-Crapsky, 2003).

${ }^{9} \mathrm{We}$ can, for instance suppose that the individual net cash flow function resulting from effort is quadratic in wealth. Summing a linear positively increasing effort function $e$ ( )and a negative quadratic cost $c($.), we get:. $f_{t, m}=e_{t, m}-c_{t, m}=b_{t, m} \cdot W_{t, m}-a_{t, m} \cdot W_{t, m}{ }^{2}$. The $a$ and $b$ coefficients will sum up the sensitivity of the increase in cashflow versus the impetus of a wealth increase due to the stock award. Quadratic costs or disutilities are usual in the literature. A continuously increasing function of cash flow gain with a strictly positive derivative will lead rational shareholders to an infinite wealth increase for the managers and executives. It would mean giving them all the equity of the firm (even if the cash flow function converges to a fixed point at infinite). The $b$ coefficient above is endogenous to managers and expresses their wealth utility and their technical capacity of extracting new cash flow by making better management decisions. It is private information for managers. The $a$ coefficient covers an induced indirect cost which can be an opportunity cost for the controlling shareholder not to give the managers the power and not to be expelled from the firm.

${ }^{10}$ We suppose an initial situation set at the political optimum where $\alpha_{0}$ is the minimum threshold to control the firm.

${ }^{11}$ Introducing explicitly the share market value can be handled in the model. It will not change the analysis, but makes it more complex by expliciting the gain linked to a lower under-diversification of the financial investment of the controlling shareholder.

${ }^{12}$ This assumption is not necessary. Here we underline that both managers and the controlling shareholder suffer from wealth under-diversification. The managers' discounting rate can be different (above or below) the one used by the controlling shareholder. Managers and executives who are awarded stocks concentrate their human capital and financial investment in the firm. We can imagine that the lower diversification will entail a specific risk premium to discount the future economic cash-flow stream. For instance, this will result in a valuation rate $r^{\prime}>r$. It doesn't change the logic of the managers/executives incentive behaviour.

${ }^{13}$ We have $d k * / d(1-\lambda)$ negative. Otherwise we get positive derivative of managers' wealth with regard to the stake of equity and the share of private benefits: $d W_{t} / d k_{t}>0$ and $d W_{t} / d(1-\lambda)>0$. These results are common sense.

${ }^{14}$ I.e. a positive value for $k$.

${ }^{15}$ We thank an anonymous referee for this remark.

${ }^{16}$ This hypothesis is pessimistic. We can imagine a reduction of the total risk if the estimation errors on the functions of effort of the managers and the executives are not correlated.

${ }^{17}$ This hypothesis will not imply that executives are inefficient. We can imagine middle executives in functional jobs who contribute in a binary form to the global creation of value of the firm. They play their role but without direct and proportional link with the operational costs or revenues. Their possible efforts will not lead to any net additional cash-flow because, for instance, the cost to attribute them to an executive's action covers the gain.

${ }^{18}$ Nor he supports any costs to evaluate the gain of cash flow by the executives or to monitor the executives' efforts.

${ }^{19}$ We saw that it will move the incentive sub-optimal contracts curve $\alpha\left(f_{t}\right)$ down and left in the plane $\left(k_{t}+k_{m}, \alpha\right)$. 